M. I. Abu-Khashaba, Innovating impermeable concrete appropriate for canal lining using a specific mixing ratio and applying it to a pilot reach, pp. 900 - 918

\title{
INNOVATING IMPERMEABLE CONCRETE APPROPRIATE FOR CANAL LINING USING A SPECIFIC MIXING RATIO AND APPLYING IT TO A PILOT REACH
}

\author{
M. I. Abu-Khashaba \\ *Associate Professor, Construction Research Institute, Delta Barrages, Egypt.
}

Received 23 March 2013, accepted 20 April 2013

\begin{abstract}
This research was initiated with the objective of innovating impermeable concrete appropriate for canal lining (i.e. to improve their function, as they lose water through evaporation, seepage and leakage) using a specific mixing ratio (i.e. adapting additives employed for linings). A new mixture (i.e. consisting of mortar, limestone powder and a chemical engineering admixture "EN-1 RBS", mainly defined as a permeability reducing admixture) was proposed to be investigated. Moreover; it was applied to a pilot reach and its effect was examined.

Different concrete and mortar mixes with/without admixture were designed and were experimentally investigated to examine the effect of EN-1 on the characteristics of both concrete and mortar mixes as well as their permeability. The examined water content ratios (w/c) were 0.45 and 0.60. EN-1 with different concentrations was also evaluated. The results proved that the permeability/microstructure of EN-1 mixes, as well as its long-term performance, was satisfactorily improved. The piezometer readings, behind the lining with EN-1, were less than that of ordinary lining which indicated the capability of EN-1 in reducing water losses. The difference in the coefficient of permeability reached $61.50 \%$ and $81 \%$ for the field and laboratory tested, respectively. For the concrete mix with w/c of 0.60 , the reduction obtained in the ISAT results was in the range of $38 \%$ to $71 \%$, using different EN-1 concentrations. Furthermore, under certain circumstances, the tensile properties, of the new mix for both concrete and mortar (with EN-1 admixture), were enhanced.
\end{abstract}

keywords: Seepage; Impermeable; Admixture; Mortar;; limestone Powder; Lining; Concentrations; Initial Surface Absorption Test, ISAT; Permeability; Piezometer.

\section{Introduction}

Open channel irrigation systems lose water through evaporation, seepage and leakage. Canals can lose 30 to $50 \%$ of their irrigation water through seepage depending on site conditions. Therefore, there is an urgent need to innovate an impermeable concrete mixture appropriate for canal lining. The presence of seepage of the flow from a canal or into it leads to a change in the bed deformation conditions and consequently the hydrodynamic characteristics of the canal. Seepage through the boundaries of alluvial canals, rivers and streams is a common occurrence due to porosity of the granular material as well due to level difference between ground water and surface water in the canal. Lining of canals could save enormous amount of water for irrigating crops. Canal-lining technologies could minimize seepage losses at reasonable costs. Traditional canal-lining materials typically include compacted earth, reinforced or plain concrete. Recently, buried geo-membranes were introduced. However, for some applications, these materials are not 
M. I. Abu-Khashaba, Innovating impermeable concrete appropriate for canal lining using a specific mixing ratio and applying it to a pilot reach, pp. 900 - 918

always viable because they are not locally available (such as compacted earth), they are too expensive (such as reinforced concrete), they require easy access for heavy construction equipment (such as slip-forming plain concrete) and finally, they require extensive over excavation and subgrade preparation (i.e. buried geo-membranes).

Networks of irrigation canals are used to convey, distribute, and apply water to the land. A canal in the network might be a rigid boundary (lined) canal or a mobile boundary (unlined) canal. As the lined canals permit higher average velocities, there is a saving in the cross-sectional area of the canal and land acquisition, with corresponding saving in the cost of excavation and masonry works. Furthermore, a lined canal can be laid on steep slopes to save the cost of earthwork in formation. On the other hand, the smooth surface of lining reduces the friction forces, which enables the canal to be laid on a flatter bed slope, with a corresponding increase in command area and a larger working head for power generation. The maintenance cost of a lined canal is less than that of unlined canals, because the lining ensures protection against bed and bank erosion. The canal lining becomes essential for stability of the canal banks in expansive soils.

Due to the importance of water conservation due to its scarcity, this research was set with the objective of innovating impermeable concrete appropriate for canal lining (i.e. to improve their function, as they lose water through evaporation, seepage and leakage) using a specific mixing ratio (i.e. adapting additives employed for linings).

The research phases are presented in this paper under the following headlines:

1. Reviewing the literature in the field of river training

2. Investigating the available admixtures and choosing EN-1 to be applied

3. Preparing the materials and investigating them

4. Designing the mixes

5. Executing experimental tests to these mixes

6. Analyzing the results and representing them

7. Applying EN-1 admixture to a pilot reach

\section{Reviewing the literature}

Primarily, the literature was reviewed in the field of river training. Based on the literature, it was found that many researchers were concerned with the problem in hand (i.e. seepage problem). Among them are:

[1] stated that the seepage losses from alluvial canals were estimated to range between $15 \%$ and $45 \%$ of the total inflow.

[2] mentioned that numerous irrigation districts lose a significant amount of water from their canal systems due to leakage.

[3] introduced a mathematical model for solving seepage problems through multi-layers of soil. The effect of water head, sub layer thickness and coefficient of permeability, on the seepage characteristics under hydraulic structures, were studied.

[4] studied the effect of clay blanket thickness to prevent seepage in dam reservoir.

[5] investigated the seepage characteristics under hydraulic structure floor, experimentally and concluded that the seepage discharge so as the hydraulic gradient values increased with increasing the permeability of the upper soil layer. When the seepage velocity is

Journal of Engineering Sciences, Assiut University, Faculty of Engineering, Vol. 41, No. 3, May, 2013,E-mail address: jes@aun.edu.eg 
M. I. Abu-Khashaba, Innovating impermeable concrete appropriate for canal lining using a specific mixing ratio and applying it to a pilot reach, pp. $900-918$

great enough, erosion might occur as a result of the frictional drag exerted on the soil particles.

[6] mentioned that erosion of the soil, known as "piping", could lead to failure of the structure and to sinkhole formation.

[7] estimated the seepage loss from canals for different sets of specific conditions.

[8] mentioned that, in the past, it was not economically feasible for agriculture to bear the costs of lining canals for seepage control. However, demands for greater agricultural production, accompanied by limitations of available land and irrigation water, enhanced the action of preventing further damage to productive lands by seepage, to reclaim those lands already damaged, in order to conserve water.

[9] explained and described the functioning of a canal network together with the basic principles of water flow in small canals. He considered the elements that affect the canal capacity.

[10] mentioned that, for sandy loam soils, seepage was significantly reduced by in-situ compaction with a vibratory roller.

[11] stated that continuous seepage from canals might cause serious water logging accompanied with salt accumulation, converting a once fertile land into a huge waste and spoil.

[12] mentioned that an efficient lining is needed to be provided in canal where canal design bed profile is below ground profile or when canal is in filling. Concrete linings have good hydraulic properties, they resist damage and minimize cleaning and weed problems. He further stated that considering the durability and limited maintenance required for canal linings, there is a considerable doubt about the annual cost of concrete linings.

\section{Investigating the available admixtures and choosing En-1 to be applied}

Based on the reviewed literature, it was clear that the cost of concrete linings is less than it was 10 years ago. Therefore, it was decided to search and investigate the available economic canal-lining mixes that are easy to construct and are compatible with severe site conditions. It was found that some researches and tests were carried out to investigate the properties of chemical engineering admixture named as EN-1. It was previously used for improving compaction in some applications such as base, sub base and asphalt layers, [13, 14]. It was also used for improving the strength of brick blocks. After the addition of EN-1 with concentrations of 1:300 and 1:500, it was found that California Bearing Ratio, CBR, for base layer was increased in the range between $109 \%$ and $194 \%$ compared to the control samples. For sub base layer, it was found that the addition of EN-1 leads to a reduction of water percentage from $11 \%$ to $9.6 \%$ which results in reducing the amount of mixing water. Results clarified also that the addition of EN-1 leads to an increase of the maximum dry density from $1.95 \mathrm{gm} / \mathrm{cm}^{3}$ to $1.97 \mathrm{gm} / \mathrm{cm}^{3}$, even with lower compaction effort. Moreover, using EN-1 increases the compaction rate by $5.4 \%$ and thereby the field density might increase. Finally, the addition of EN-1 increased the CBR by $89 \%$. Based on the above inspections and investigations, EN-1 was chosen to be applied in the present research.

Journal of Engineering Sciences, Assiut University, Faculty of Engineering, Vol. 41, No. 3, May, 2013, E-mail address: jes@aun.edu.eg 
M. I. Abu-Khashaba, Innovating impermeable concrete appropriate for canal lining using a specific mixing ratio and applying it to a pilot reach, pp. $900-918$

\section{Preparing and investigating the materials}

Based on the above, the materials were prepared and investigated. The ordinary Portland cement was used in all mixes. The well graded gravel was used as a coarse aggregate and naturally siliceous sand was used as a fine aggregate. Sieve analysis test was carried out and their results are given in figure (1), while the results of the different mechanical properties (i.e. bulk density, specific gravity...etc.) are listed in table (1), for both sand and gravel.

\section{Table 1.}

Different mechanical properties of gravel and sand

\begin{tabular}{ccccc}
\hline \hline $\begin{array}{c}\text { Aggregate } \\
\text { type }\end{array}$ & Bulk density $\left(t / \mathrm{m}^{3}\right)$ & $\begin{array}{c}\text { Specific } \\
\text { gravity }\end{array}$ & $\begin{array}{c}\text { Voids ratio } \\
(\%)\end{array}$ & $\begin{array}{c}\text { Absorption } \\
(\%)\end{array}$ \\
\hline Gravel & 1.63 & 2.54 & 35.85 & 0.41 \\
Sand & 1.78 & 2.60 & 31.60 & - \\
\hline \hline
\end{tabular}

A chemical engineering admixture EN-1 RBS was supplied by the worldwide manufacturing company defined mainly as a permeability reducing admixture was used in some mixes, admixture concentrations of 1/500, 1/300, and 1/100 from water volume, were used for all mixes. The chemical composition of the EN-1 admixture is mainly sulfuric acid, and therefore some investigations were applied to the materials in order to determine the chemical effect, engineering and physical properties of the mixes containing EN-1 (i.e. alum test, bio-tests, permeability...etc.).

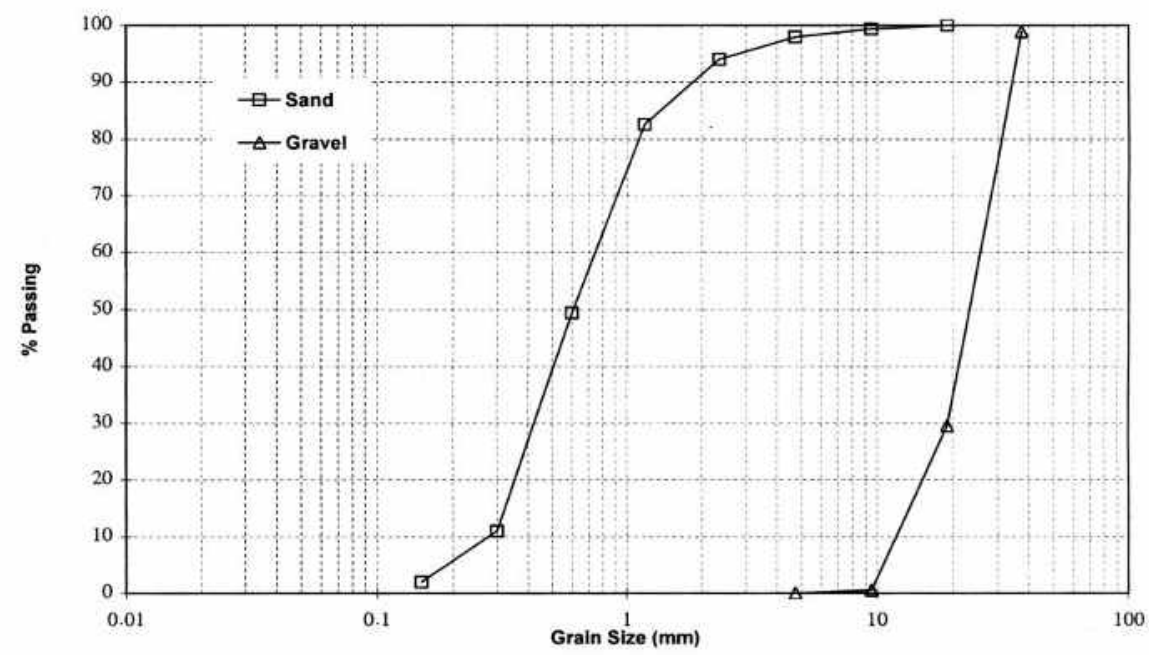

Fig. 1. Sieve analysis for both gravel and sand

Journal of Engineering Sciences, Assiut University, Faculty of Engineering, Vol. 41, No. 3, May, 2013,E-mail address: jes@aun.edu.eg 
M. I. Abu-Khashaba, Innovating impermeable concrete appropriate for canal lining using a specific mixing ratio and applying it to a pilot reach, pp. 900 - 918

These tests were conducted in the National Research Center Laboratory in order to define the effect of EN-1 admixture on the $\mathrm{pH}$ value as well as its effect on the water running in the canals. All these tests proved that there is no negative effect on both water quality as well as $\mathrm{pH}$ value. Moreover, the tests concluded also that it is non-toxic and it has no biological effect since it does not help for microbial growth.

\section{Designing the mixes}

Generally, both mortar and concrete mixes were conducted. All mortar mixes were made with w/c ratio of 0.60. All concrete mixes were designed according to ACI 211 (Absolute volume method) and their different mix proportions are listed in table (2). Eight (8) concrete mixes and four (4) mortar mixes were designed and tested in the first phase. Furthermore, in the 2-nd phase, additional 3 mixes having the same proportions of both mortar and concrete mixes were applied in the canal lining in nature, as a case study. For mortar mixing process:

1. All mixing water was put in the mixer.

2. Cement was added to the water and mixing operation lasted for 30 second at low speed.

3. Sand was added through 30 seconds during mixing.

4. The mixer was stopped and the speed was changed to a higher speed then mixing continued for 30 seconds.

5. The mixer is stopped and the mix was left for 90 seconds.

6. For the first 15 seconds the mortar at the edges was collected and the next 75 seconds the mixer was being covered and left till the end of the period.

7. The mixer was operated again at the high speed for 60 seconds.

Table 2.

Concrete/mortar mix proportions $\left(\mathrm{kg} / \mathrm{m}^{3}\right)$

\begin{tabular}{rrrrrrrc}
\hline \hline Mix & W/C & Cement & Water & Sand & Gravel & EN-1 & Lime stone powder \\
\hline 1 & 0.45 & 350 & 157.5 & 634 & 1238.5 & $*$ & - \\
2 & 0.60 & 350 & 210 & 932 & 900 & $*$ & - \\
3 & 0.60 & 350 & 210 & 932 & - & $*$ & - \\
4 & 0.60 & 350 & 210 & 932 & - & 0.798 & 424 \\
5 & 0.60 & 350 & 210 & 932 & - & - & 424 \\
\hline \hline
\end{tabular}

Both concrete mix 2 without admixture and mortar mix 4 were applied in the field. *EN-1 admixture was used with different concentration 1/500, 1/300, \& 1/100.

\section{Executing experimental tests}

After preparing the mixes, tests were executed (i.e. fresh properties tests and hardened properties tests). The coming section is devoted to present the execution of these tests.

Journal of Engineering Sciences, Assiut University, Faculty of Engineering, Vol. 41, No. 3, May, 2013,E-mail address: jes@aun.edu.eg 
M. I. Abu-Khashaba, Innovating impermeable concrete appropriate for canal lining using a specific mixing ratio and applying it to a pilot reach, pp. $900-918$

\subsection{Fresh Properties Tests}

Among the fresh properties tests were the penetration resistance test and flow test of mortar. These are discussed as below.

\subsubsection{Penetration resistance tests}

After mixing operation took place, the mortar was placed in a 70x70x70 mm cube. The cube was set in the mechanical vibrator for two minutes and then smoothing to its surface took place. The cube was left for 30 minutes from the mixing instant and then the first reading was taken using pocket penetrometer $20 \mathrm{~mm}$ away from the corners. Readings were taken every 30 minutes taking into consideration keeping holes $25 \mathrm{~mm}$ apart. The initial setting was detected at the reading of 3.200 MPa.

\subsubsection{Flow test of mortar}

A cone of inner diameter of $70 \mathrm{~mm}$, an outer diameter of $100 \mathrm{~mm}$ and height of $50 \mathrm{~mm}$ was centered with the disk. The cone was filled in two layers; each layer was compacted 15 times using compaction bar. The cone was raised up. The handle was rotated with a speed not more than 100 cycles/min in order to cause 25 impacts to the mortar. Measuring the mortar diameters in four directions after the flow, then the maximum and the minimum diameters were taken into consideration. The average value of measurement was recorded and was substituted into equation (1).

$$
\text { Flow }(\%)=\frac{\text { Averagevalue }-100}{100} * 100 \%
$$

\subsection{Hardened Properties Tests}

Among the hardened properties tests were the compressive strength tests so as the direct tensile strength, splitting and flexure tests:

\subsubsection{Compressive strength test}

The specimen was set in the compressive strength machine at one of its sides and a gradual loading of $35 \mathrm{~N} / \mathrm{mm}^{2} / \mathrm{min}$ was applied till failure occurred and the failure load was detected. The compressive strength was calculated using equation (2).

$$
f_{c}\left(N / \mathrm{mm}^{2}\right)=\frac{\text { Average failure load for three samples }(\mathrm{N})}{\text { Area subjected to load }\left(\mathrm{mm}^{2}\right)}
$$

\subsubsection{Direct tensile strength, splitting and flexure test}

After mortar mixing, it was placed in the standard mould and compressed with thumb 12 times on its whole surface. Then some extra mortar was added in the mould and its surface was smoothened. The mould was placed in a curing chamber for 24 hours. The samples were released from moulds and then placed in curing pool till the time of test. At the day of test, (28-days age), the samples were released from curing pool and dried with a wet piece

Journal of Engineering Sciences, Assiut University, Faculty of Engineering, Vol. 41, No. 3, May, 2013,E-mail address: jes@aun.edu.eg 
M. I. Abu-Khashaba, Innovating impermeable concrete appropriate for canal lining using a specific mixing ratio and applying it to a pilot reach, pp. 900 - 918

of cloth. The mortar sample was set in the tensile strength machine and a gradual loading of 400N/10 sec was exerted from zero till failure occurred. The tensile strength was calculated using the average failure load of six samples using equation (3).

$$
f_{t}\left(\mathrm{~N} / \mathrm{mm}^{2}\right)=\frac{\text { Average tensile load for six samples }(\mathrm{N})}{\text { Area subjected toload }\left(\mathrm{mm}^{2}\right)}
$$

The tensile splitting strength was then det ermined using equation (4).

$f_{s p}\left(N / m^{2}\right)=\frac{2 F(N)}{\pi d L\left(m m^{2}\right)}$

where:

F: Failure load (N)

L: Length of cylinder ( $\mathrm{mm})$

$\mathrm{d}$ : Diameter of cylinder $(\mathrm{mm})$

Moreover, the flexural strength was determined through equation (5):

$f_{f l x}\left(N / m m^{2}\right)=\frac{F L}{d_{1} d^{2}{ }_{2}}$

where:

F: Failure load in (Newton)

L: beam span in $(\mathrm{mm})$

$\mathrm{d}_{1}$ : beam width in $(\mathrm{mm})$

$\mathrm{d}_{2}$ : beam depth in $(\mathrm{mm})$

\section{Analyzing the results and representing them}

After executing the tests, results were obtained, analyzed and represented. The results of the testing program are shown in the tables (3) to (8). The testing program is directed to compare between the fresh and hardened properties of mortar/concrete mixes with the identical properties for EN-1 admixture mixes.

The investigated fresh properties were flow loss and initial setting time for mortar and slump, slump loss, initial and final setting time for concrete while the examined hardened properties were compressive strength, direct tension, absorption for mortar and compressive, flexural, and splitting strength, absorption for concrete.

Journal of Engineering Sciences, Assiut University, Faculty of Engineering, Vol. 41, No. 3, May, 2013, E-mail address: jes@aun.edu.eg 
M. I. Abu-Khashaba, Innovating impermeable concrete appropriate for canal lining using a specific mixing ratio and applying it to a pilot reach, pp. $900-918$

\subsection{Mortar fresh properties}

As shown in figure (2), the plotted results clarify that no major changes are noticed in the flow test results during the first 45 minutes. Beyond this time, the flow of the EN-1 mortar mixes reached zero. This is explained due to the workability loss with time especially with EN-1 inclusion which is more or less comparable with that of concrete mixture having the same $\mathrm{w} / \mathrm{c}$ ratio of 0.60 .

\subsection{Mortar hardened properties}

Results of hardened properties for different mortar mixes are shown in table (3). They indicated that no major changes were noticed in the compressive strength values. Compressive strength for mortar mixes with EN-1 showed small increments in the range of 2.5\% (lower EN-1 concentration) to 10\% (higher concentration) during 7 days and 28 days compared with the control mix as presented in figure (3). Values of the direct tensile strength of the EN-1 mortar mixes were found to be lower than that of the control mix except with the mix containing 1:500 EN-1 which showed a slight increase of about 4.50 $\%$ as listed in table (3). Slight improvements were achieved with regard to water absorption results; using the EN-1with higher concentration of 1:100 an increase of about $6 \%$ was obtained.

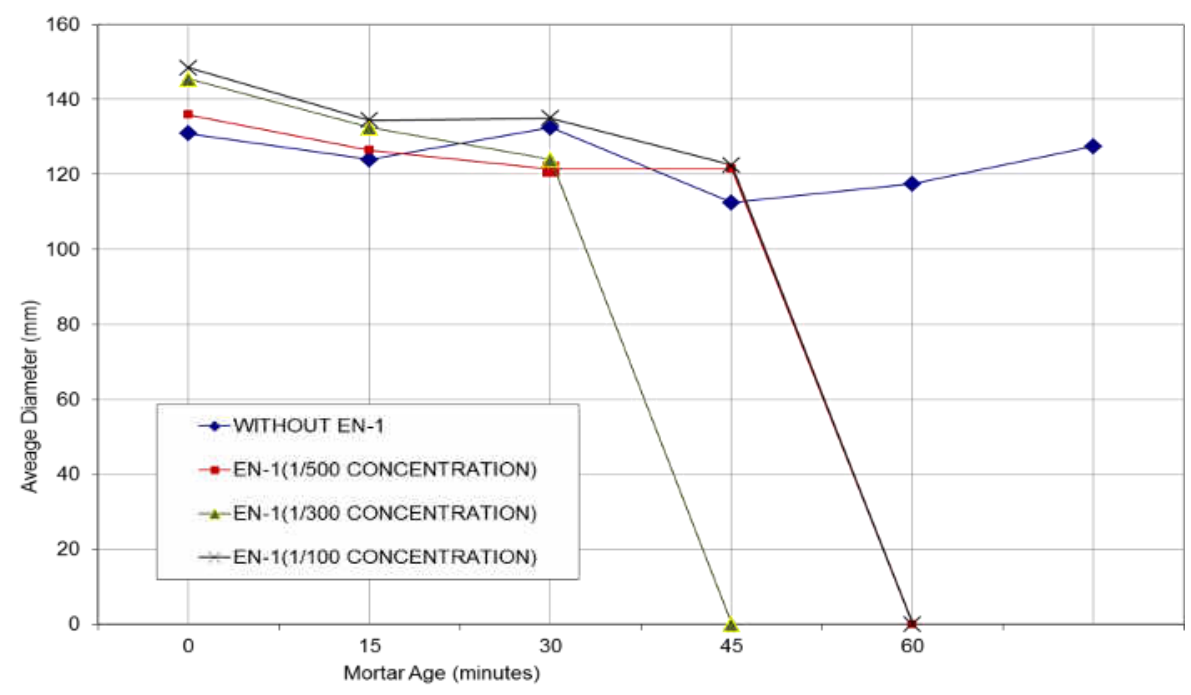

Fig. 2. Flow loss test of mortar

Journal of Engineering Sciences, Assiut University, Faculty of Engineering, Vol. 41, No. 3, May, 2013, E-mail address: jes@aun.edu.eg 
M. I. Abu-Khashaba, Innovating impermeable concrete appropriate for canal lining using a specific mixing ratio and applying it to a pilot reach, pp. $900-918$

\section{Table 3.}

Results of fresh and hardened properties for mortar mixes

\begin{tabular}{|c|c|c|c|c|c|c|}
\hline \multirow[t]{3}{*}{ Mix. type } & \multirow[t]{3}{*}{ Symbol } & \multirow{3}{*}{$\begin{array}{l}\text { I.S.T } \\
\text { (hrs) }\end{array}$} & \multicolumn{2}{|c|}{$\begin{array}{l}\text { Compressive } \\
\text { strength, } f_{c}\end{array}$} & \multirow{2}{*}{$\begin{array}{c}\begin{array}{c}\text { Direct } \\
\text { tensile } \\
\text { strength, } \boldsymbol{f}_{\boldsymbol{t}}\end{array} \\
\left(\mathrm{N} / \mathrm{mm}^{2}\right)\end{array}$} & \multirow{2}{*}{$\begin{array}{c}\text { Absorption } \\
(\%)\end{array}$} \\
\hline & & & & $\left.n m^{2}\right)$ & & \\
\hline & & & 7days & 28 days & 28 days & 28 days \\
\hline Without Admix. & 0 & 2.25 & 23.95 & 29.25 & 3.08 & 8.63 \\
\hline With EN-1, 1/500 & $1 / 500$ & 1.6 & 28.23 & 29.93 & 3.22 & 8.83 \\
\hline With EN-1, 1/300 & $1 / 300$ & 1.8 & 29.58 & 31.97 & 2.66 & 8.64 \\
\hline With EN-1, 1/100 & $1 / 100$ & 2 & 28.23 & 32.48 & 2.33 & 9.13 \\
\hline
\end{tabular}

\subsection{Results of fresh properties for concrete mixes}

Despite the small difference between the used w/c ratio $(0.45 \& 0.60)$, the inclusion of EN-1 has a completely different behavior in each one. Initial and final setting time of concrete were increased compared with the control for the $0.45 \mathrm{w} / \mathrm{c}$ ratio concrete mixes as shown in table (4). An opposite trend was obtained with the $0.60 \mathrm{w} / \mathrm{c}$ ratio. The workability of concrete in terms of slump was decreased with the addition of EN-1 for both w/c ratios of (0.45 and 0.60) except for one mix where the slump was increased as given in figure (4). A minimal slump loss was obtained with the addition of EN-1 as shown in figure (5).

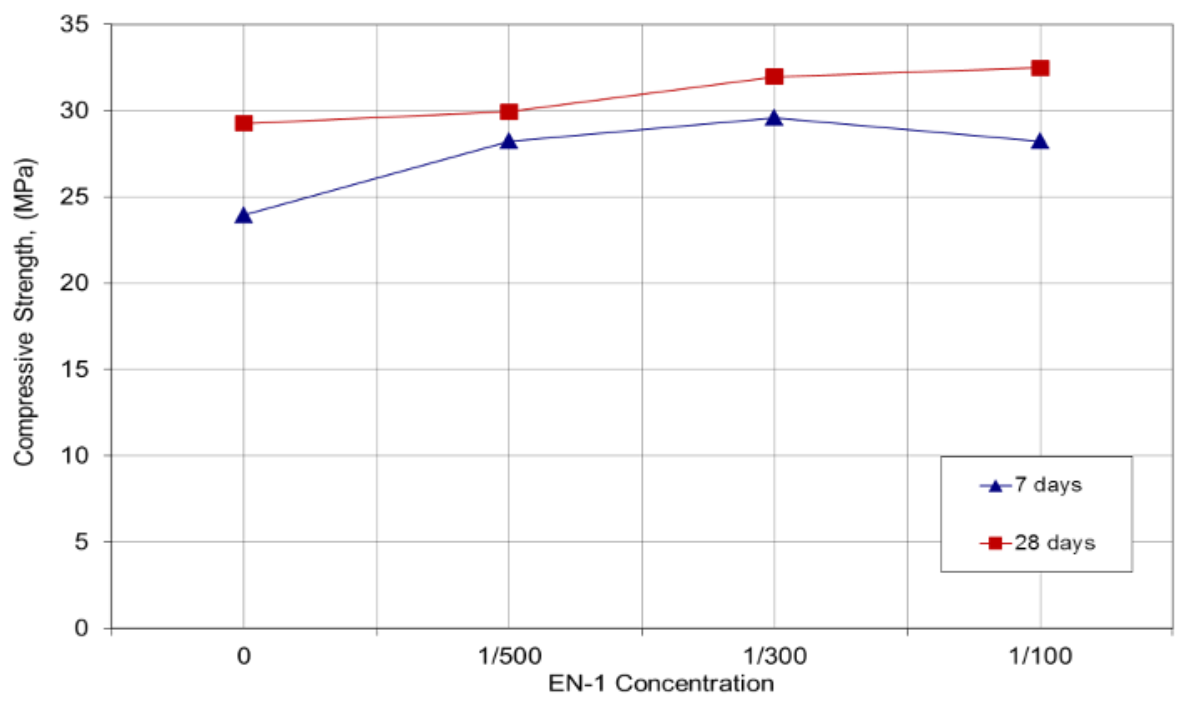

Fig. 3. Effect of EN-1 admixture on compressive strength of mortar

Journal of Engineering Sciences, Assiut University, Faculty of Engineering, Vol. 41, No. 3, May, 2013,E-mail address: jes@aun.edu.eg 
M. I. Abu-Khashaba, Innovating impermeable concrete appropriate for canal lining using a specific mixing ratio and applying it to a pilot reach, pp. $900-918$

\section{Table 4.}

Slump and setting time of concrete mixes

\begin{tabular}{ccccc}
\hline \hline \multirow{2}{*}{ w/c } & Mix & $\begin{array}{c}\text { Slump } \\
(\mathrm{mm})\end{array}$ & \multicolumn{2}{c}{ Setting time $(\mathrm{hrs.})$} \\
& & & Initial & Final \\
\hline \multirow{4}{*}{0.45} & $1 / 500$ & 90.5 & 4 & 5.5 \\
& $1 / 300$ & 155 & 6 & 8.5 \\
& $1 / 100$ & 50 & 6.25 & 8 \\
& 0 & 210 & 7.3 & 5.75 \\
0.60 & $1 / 500$ & 170 & 5 & 9 \\
& $1 / 300$ & 155 & 5.25 & 7 \\
& $1 / 100$ & 140 & 5.5 & 7 \\
\hline \hline
\end{tabular}

\subsection{Effect of EN-1 on hardened properties of concrete mixes}

For w/c of 0.45 , the obtained compressive strength values of EN-1 concrete were lower than that of the normal concrete, except for higher EN-1 concentration, (1/100) which has a slight increase of about $4.5 \%$ as clearly shown in table (5) and figure (6). However, for w/c ratio of 0.60 , a slight increase in the values of compressive strength results was obtained after 7 and 28 days as shown in figure (7). For both flexure and splitting strength, no major change was obtained with the addition of EN-1, especially with w/c ratio of 0.60 , while a variation of about $23.50 \%$ and $14.50 \%$ was achieved with the results of flexural and splitting tensile strength for the mix having smaller EN-1 concentration (i.e. 1/500 and $0.45 \mathrm{w} / \mathrm{c}$ ratio) as listed in table (5).

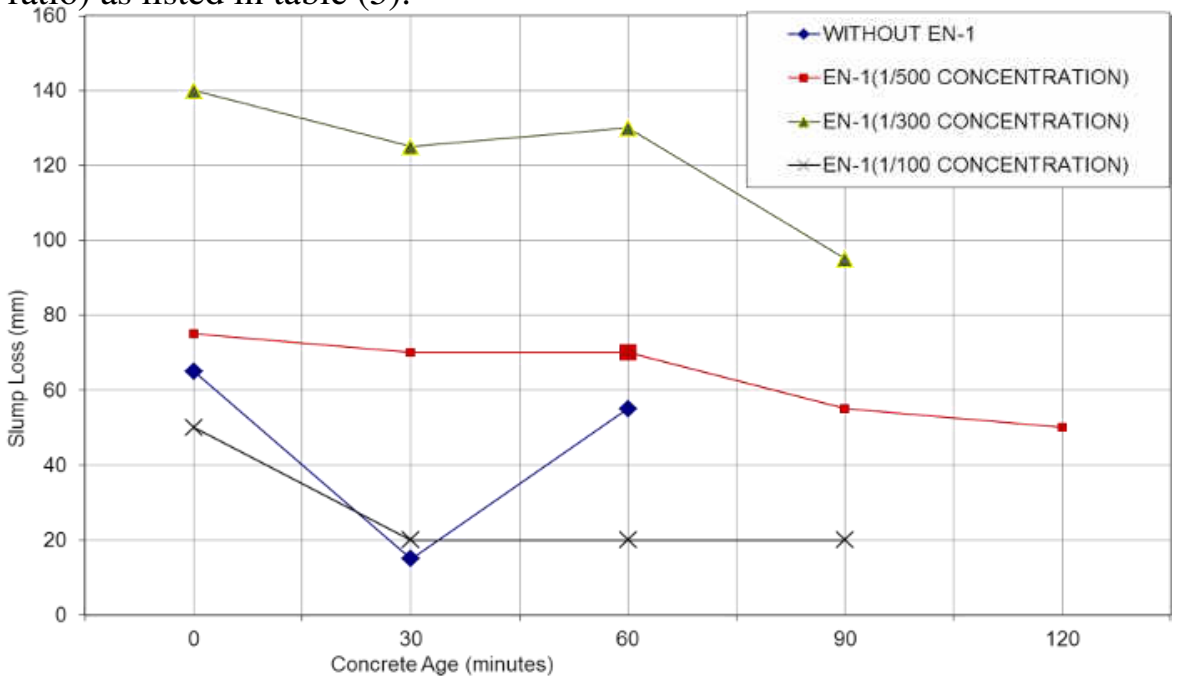

Fig . 4. Slump loss versus age of concrete, $(w / c=0.45)$

Journal of Engineering Sciences, Assiut University, Faculty of Engineering, Vol. 41, No. 3, May, 2013,E-mail address: jes@aun.edu.eg 
M. I. Abu-Khashaba, Innovating impermeable concrete appropriate for canal lining using a specific mixing ratio and applying it to a pilot reach, pp. $900-918$

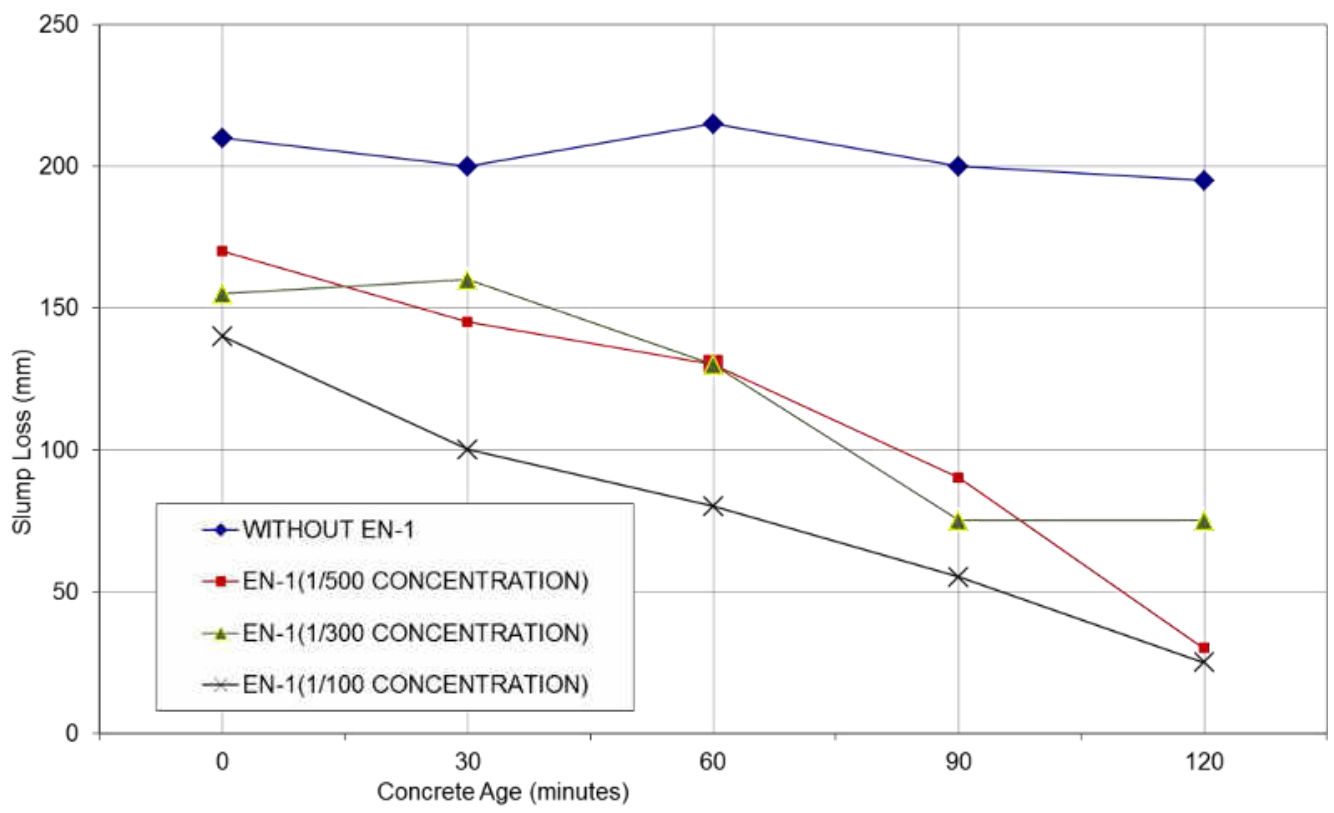

Fig. 5. Slump loss versus age of concrete, $(\mathbf{w} / \mathbf{c}=\mathbf{0 . 6 0})$

Table 5.

Hardened properties of concrete mixes

\begin{tabular}{|c|c|c|c|c|c|c|c|c|c|c|}
\hline \multirow[t]{2}{*}{ w/c } & \multirow[t]{2}{*}{ Mix } & \multicolumn{2}{|c|}{$\begin{array}{c}\text { Compressive } \\
\text { strength, } \\
f_{c}\left(\mathrm{~N} / \mathrm{mm}^{2}\right)\end{array}$} & \multicolumn{2}{|c|}{$\begin{array}{l}\text { Flexural } \\
\text { strength, } \\
f_{f}\left(\mathrm{~N} / \mathrm{mm}^{2}\right)\end{array}$} & \multirow{2}{*}{$\begin{array}{c}\text { Splitting } \\
\text { strength, } \\
f_{s p t}\left(N / \mathrm{mm}^{2}\right) \\
28 \\
\text { days }\end{array}$} & \multirow{2}{*}{$\begin{array}{c}\begin{array}{l}\text { Absor } \\
\text { ption }\end{array} \\
(\%) \\
\begin{array}{c}28 \\
\text { days }\end{array}\end{array}$} & \multirow{2}{*}{$\begin{array}{c}\text { U.P.V* } \\
(\mathrm{km} / \mathrm{s}) \\
28 \\
\text { days }\end{array}$} & \multicolumn{2}{|c|}{$\begin{array}{c}\text { ISAT } * * \\
(\text { flow } \\
\left.\mathrm{mm} / \mathrm{m}^{2} / \mathrm{sec}\right)\end{array}$} \\
\hline & & $\begin{array}{c}7 \\
\text { days }\end{array}$ & $\begin{array}{c}28 \\
\text { days }\end{array}$ & $\begin{array}{c}7 \\
\text { days }\end{array}$ & $\begin{array}{c}28 \\
\text { days }\end{array}$ & & & & $\begin{array}{c}10 \\
\min \end{array}$ & $\begin{array}{c}30 \\
\text { min }\end{array}$ \\
\hline \multirow{4}{*}{0.45} & 0 & 23.85 & 31.52 & 4.92 & 6.59 & 2.55 & 3.69 & 4.93 & 0.259 & 0.095 \\
\hline & $1 / 500$ & 22.44 & 28.78 & 5.20 & 8.13 & 2.92 & 4.43 & 5.05 & 0.205 & 0.073 \\
\hline & $1 / 300$ & 20.18 & 26.59 & 4.68 & 6.30 & 2.49 & 4.50 & 4.83 & 0.261 & 0.070 \\
\hline & $1 / 100$ & 30.44 & 32.96 & 4.65 & 6.06 & 2.33 & 2.92 & 4.86 & 0.220 & 0.068 \\
\hline \multirow{4}{*}{0.60} & 0 & 12.37 & 18.70 & 4.47 & 5.13 & 2.65 & 4.58 & 4.77 & 0.513 & 0.533 \\
\hline & $1 / 500$ & 15.85 & 20.22 & 4.14 & 4.44 & 2.02 & 4.46 & 4.64 & 0.494 & 0.333 \\
\hline & $1 / 300$ & 17.41 & 21.26 & 4.47 & 5.01 & 2.39 & 4.42 & 4.56 & 0.290 & 0.180 \\
\hline & $1 / 100$ & 14.04 & 18.89 & 4.14 & 4.97 & 2.12 & 3.61 & 4.53 & 0.364 & 0.155 \\
\hline
\end{tabular}

*Ultra sonic pulse velocity, and ** Initial surface absorption test

Journal of Engineering Sciences, Assiut University, Faculty of Engineering, Vol. 41, No. 3, May, 2013,E-mail address: jes@aun.edu.eg 
M. I. Abu-Khashaba, Innovating impermeable concrete appropriate for canal lining using a specific mixing ratio and applying it to a pilot reach, pp. $900-918$

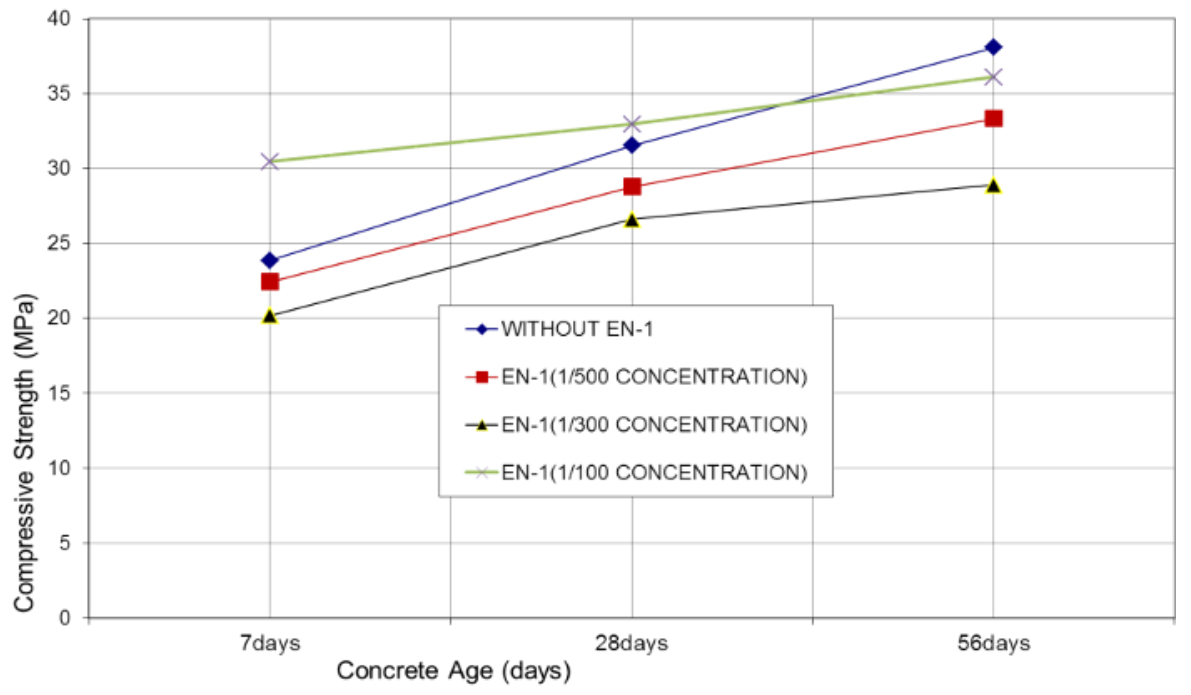

Fig. 6. Compressive strength for concrete of $w / c=0.45$

The results of the ISAT test for w/c ratio of $(0.45 \& 0.60)$ are shown in table (5) and figure (8). A remarkable improvement was achieved with the addition of EN-1 that reflects the enhancements gained in the concrete permeability/microstructure. For the w/c of 0.60 , the reduction obtained in the ISAT results were increased with increasing EN-1 concentration, reduction percentages of $37.5 \%, 66 \%$ and $71 \%$ were obtained with EN-1 concentrations of 1:500, 1:300 and 1:100, respectively, as clearly given in figure (8). These obtained values were a little smaller to be $23 \%, 26.50 \%$, and $28.50 \%$.

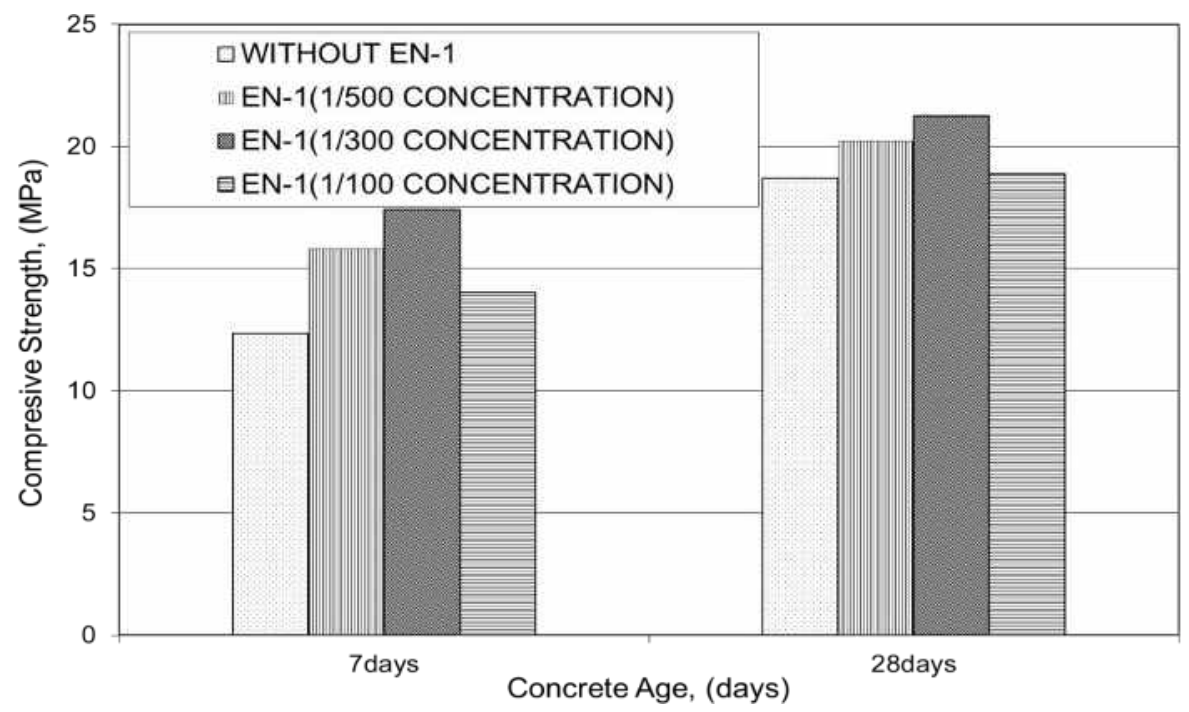

Fig. 7. Compressive strength for concrete of $w / c=0.60$

Journal of Engineering Sciences, Assiut University, Faculty of Engineering, Vol. 41, No. 3, May, 2013, E-mail address: jes@aun.edu.eg 
M. I. Abu-Khashaba, Innovating impermeable concrete appropriate for canal lining using a specific mixing ratio and applying it to a pilot reach, pp. $900-918$

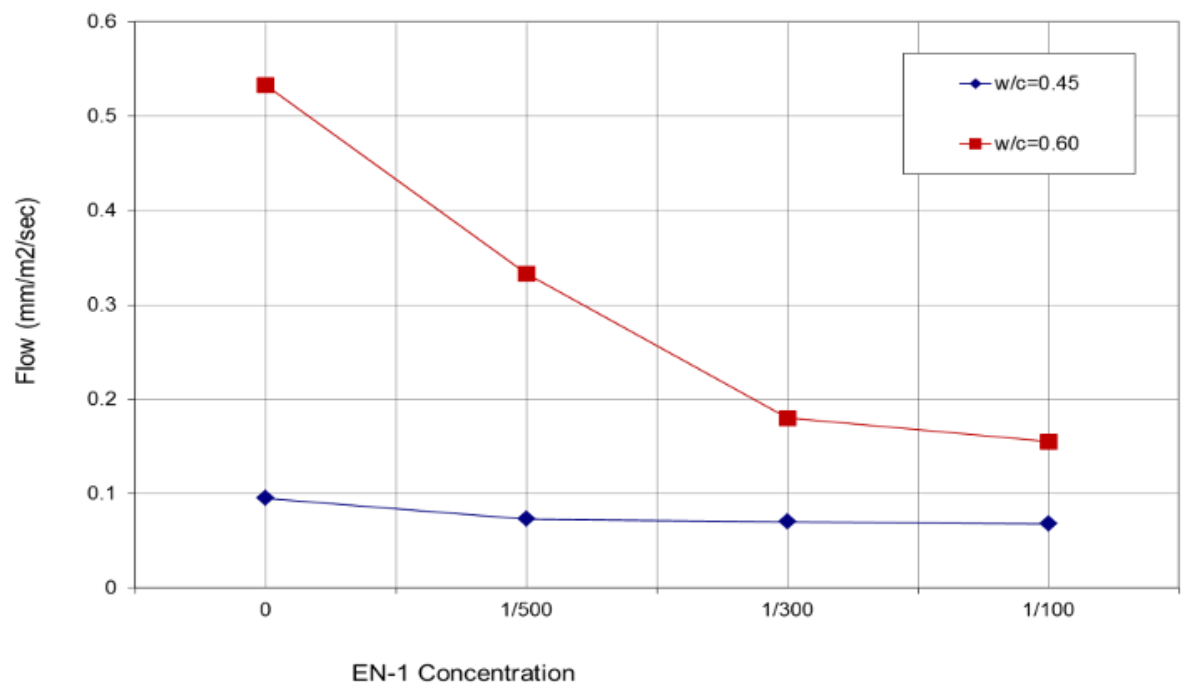

Fig. 8. Initial surface absorption (ISAT) after 30 minutes for concrete mixes

\section{Applying EN-1 admixture to a pilot reach}

Confident with the results obtained from the investigations executed to EN-1 admixture, it was applied to a pilot area. The carried out field work so as the experimental tests and their results are represented in this section.

\subsection{Field works and experimental tests}

To evaluate the effectiveness of using EN-1 as an admixture for the new proposed mix in lining works for canals and drains, the new proposed lining was applied to a reach, of about $47 \mathrm{~m}$ in branch (2) along the right side of El-Nasr Canal, as a pilot reach, figure (9). Also, a similar portion was lined using the traditional concrete lining, [13, 14]. The lining evaluation process was carried out through the following steps:

1. Field visits were carried out to inspect the site where simple capillary cracks were observed. These cracks were not deep in the innovative and traditional lining.

2. A group of cylindrical cores were extracted from the innovative and traditional linings. The compressive strength as well as the coefficient of permeability for the extracted samples was determined and the results are listed in table (6).

3. Piezometers were installed into the embankment behind both linings on the left side of the canal, figure (10) to monitor the water head behind both linings.

4. Conducting additional 3 laboratory mixes with the same constituents listed in table (2). The first two experimentally investigated mixes had the same proportions that were applied for canal lining as a case study (one for the proposed mortar, (mix 4),

Journal of Engineering Sciences, Assiut University, Faculty of Engineering, Vol. 41, No. 3, May, 2013,E-mail address: jes@aun.edu.eg 
M. I. Abu-Khashaba, Innovating impermeable concrete appropriate for canal lining using a specific mixing ratio and applying it to a pilot reach, pp. $900-918$

and one for traditional concrete, $(\operatorname{mix} 2)$ ), while the third mix had the same proportions of the mortar mix, (mix 5), but without the EN-1 admixture. The compressive strength as well as the coefficient of permeability for the laboratory mixes were also determined and listed in table (6).

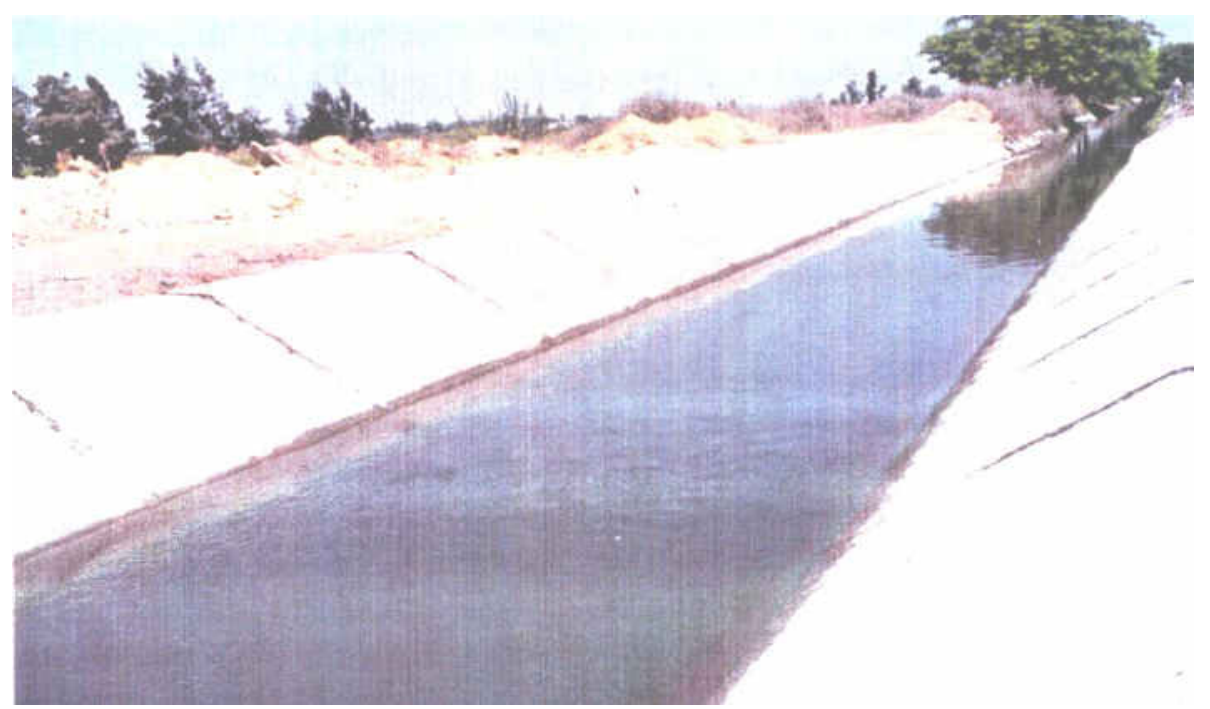

Fig. 9. The innovative lining applied to a canal reach

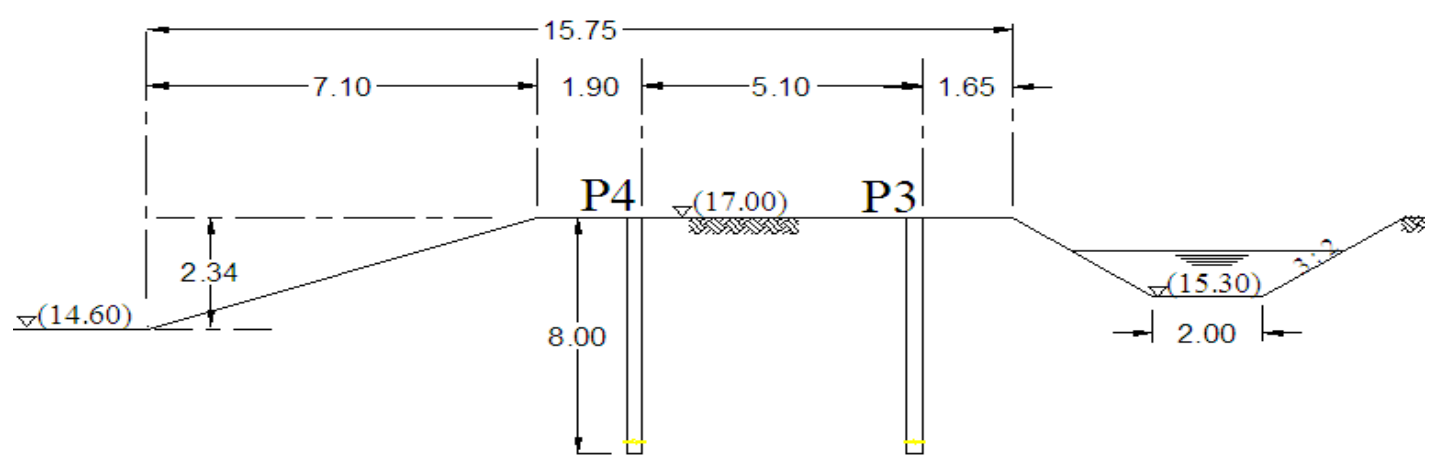

Fig. 10. Installed piezometers to monitor water level behind lining

Journal of Engineering Sciences, Assiut University, Faculty of Engineering, Vol. 41, No. 3, May, 2013,E-mail address: jes@aun.edu.eg 
M. I. Abu-Khashaba, Innovating impermeable concrete appropriate for canal lining using a specific mixing ratio and applying it to a pilot reach, pp. $900-918$

\section{Table 6.}

Compressive strength, $\left(\mathrm{f}_{\mathrm{c}}\right)$ and coefficient of permeability, $(\mathrm{k})$ for field and laboratory samples

\begin{tabular}{lcccccc}
\hline \hline \multirow{2}{*}{ Mix type } & \multicolumn{3}{c}{ Lab samples } & \multicolumn{3}{c}{ Field samples } \\
& \multicolumn{2}{c}{$\mathbf{f}_{\mathbf{c}}\left(\mathrm{N} / \mathrm{mm}^{2}\right)$} & $\mathbf{k}(\mathrm{cm} / \mathrm{s})$ & $\mathbf{f}_{\mathbf{c}}\left(\mathrm{N} / \mathrm{mm}^{2}\right)$ & $\mathbf{k}(\mathrm{cm} / \mathrm{s})$ \\
\cline { 2 - 7 } & 7 days & 28 days & 28 days & 7 days & 28 days & 28 days \\
Concrete & 17.7 & 25.1 & $1.22 * 10^{-7}$ & 13.73 & 18.23 & $3.56 * 10^{-7}$ \\
Mortar with EN-1 & 20.1 & 33.8 & $0.23 * 10^{-7}$ & 9.90 & 13.05 & $1.37 * 10^{-7}$ \\
Mortar without EN-1 & 25.6 & 31.3 & $0.26 * 10^{-7}$ & N/A & N/A & N/A \\
\hline \hline
\end{tabular}

\subsection{Results of long-term performance tests}

A group of cylindrical cores of diameter of $75 \mathrm{~mm}$ was extracted from the innovative and traditional linings (i.e. with and without $\mathrm{EN}-1$ ) after one year, to investigate the performance of EN-1, on the long-term. The compressive and splitting strengths were investigated and the following results were listed in table (7).

From the obtained results, listed in both tables (6) and (7), it was concluded that:

1. Average compressive strength, after 28 days, for the samples of lining containing EN-1 exceeded by $35 \%$ than the traditional lining.

2. Piezometers readings for the lining with EN-1 are generally less than that the traditional lining. This indicated the effectiveness of EN-1 admixture in lining process as it minimizes the water head behind lining as shown in figure (11). This means a reduction in water loss from the canal. This result is confirmed again since coefficient of permeability for core samples extracted from EN-1 lining is much less than that of the traditional lining by $61.50 \%$.

3. The average value of coefficient of permeability for laboratory samples of lining containing EN-1 are less than the traditional lining by more than $81 \%$. This is more or less comparable with that of using lime stone powder in the mix. This clarifies the effectiveness of using both EN-1 admixture and the powder.

4. The results of the long-term performance for the applied mixes which were evaluated, after one year, (i.e. in terms of both compressive and tensile strengths) showed that the compressive strength of the new proposed mix increases gradually with time which ensures its efficiency, while its tensile strength decreases compared to the traditional concrete mix by about $50 \%$ which might be attributed to the absence of coarse aggregate.

Journal of Engineering Sciences, Assiut University, Faculty of Engineering, Vol. 41, No. 3, May, 2013,E-mail address: jes@aun.edu.eg 
M. I. Abu-Khashaba, Innovating impermeable concrete appropriate for canal lining using a specific mixing ratio and applying it to a pilot reach, pp. $900-918$

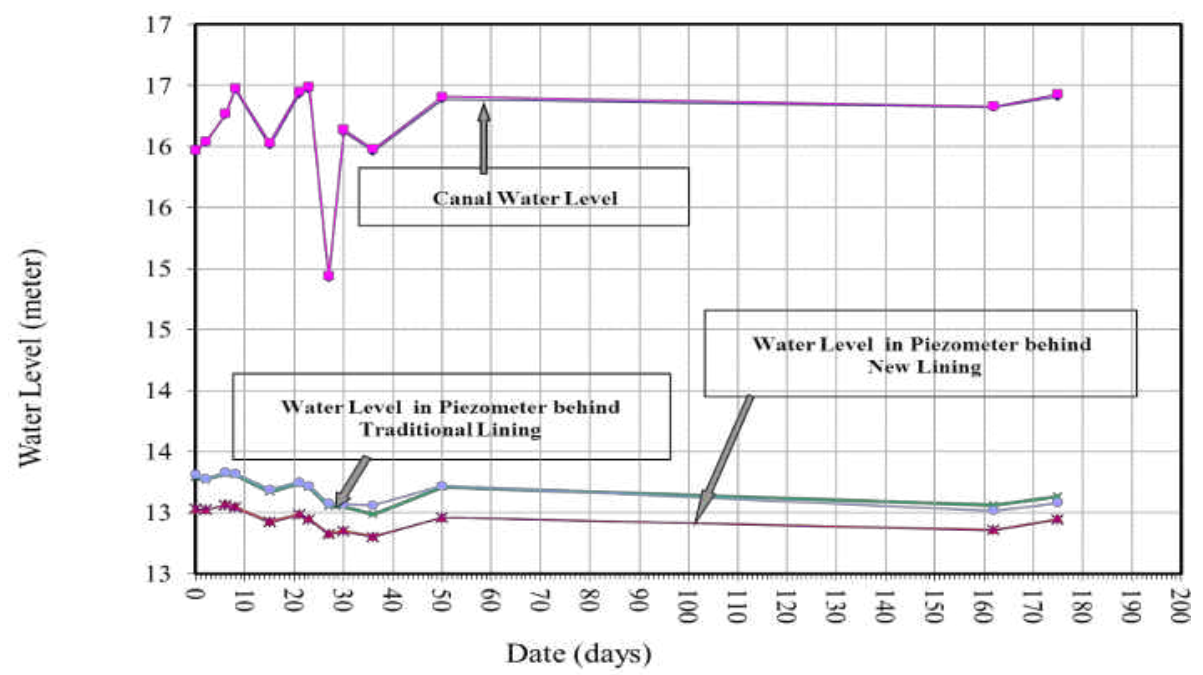

Fig. 11. In-situ measured permeability for the innovative and traditional lining

\section{Table 7.}

Results of compressive, splitting strength for cores extracted from the innovative and traditional linings after one year $\left(\mathrm{N} / \mathrm{mm}^{2}\right)$

\begin{tabular}{lccccc}
\hline \hline \multirow{2}{*}{ Type of lining } & \multicolumn{2}{c}{ Compressive strength } & \multicolumn{2}{c}{ Splitting strength } & Extracted \\
& 1-year & 28-days & 1-year & 28-days & core place \\
& 282.60 & 212.13 & - & - & \\
Lining with & 188.82 & 141.66 & 14.36 & 13.64 & canal bed \\
Invented mortar & 218.43 & 163.80 & - & - & upper level of \\
& 312.03 & 234.00 & - & - & canal \\
Normal lining & 207.99 & 155.97 & 26.57 & 25.23 & canal bed \\
\hline \hline
\end{tabular}

\section{Conclusions}

Based on the executed tests, examinations, pilot reach results, it was concluded that: Implementing EN-1 with concrete/mortar indicated some results that can be summarized as follows:

1. For laboratory mortar mixes, the obtained results showed small increments in the range of $10 \%$ after 7 days and 28 days using EN-1 mix. However, the direct tensile strength for the EN-1 mortar mixes are found to be lower than that of the control mix except for the mix containing EN-1 with concentration of 1:500 which showed a slight increase of about $10 \%$.

2. As for concrete laboratory specimens, initial and final setting time of concrete was increased compared to the control for the $0.45 \mathrm{w} / \mathrm{c}$ ratio concrete mix. An opposite

Journal of Engineering Sciences, Assiut University, Faculty of Engineering, Vol. 41, No. 3, May, 2013, E-mail address: jes@aun.edu.eg 
M. I. Abu-Khashaba, Innovating impermeable concrete appropriate for canal lining using a specific mixing ratio and applying it to a pilot reach, pp. $900-918$

trend was obtained with the $0.60 \mathrm{w} / \mathrm{c}$ ratio. The concrete slump is decreased with the addition of EN-1 for both w/c ratios of (0.45 and 0.60). A minimal slump loss was obtained with the addition of EN-1.

3. No definite pattern was obtained with the compressive strength results of concrete with w/c of 0.45; a slight increase in the values of compressive strength results was obtained after 7 days and 28 days for w/c ratio of 0.60 .

4. For flexure strength, no major change was obtained with the addition of EN-1 especially with w/c ratio of 0.60 . A variation of about $10 \%$ to $20 \%$ was obtained with the results of splitting tensile strength.

5. Regarding the permeability, a major improvement was achieved with the addition of EN-1, which reflects the enhancements that took place in the concrete permeability/microstructure as well as its long-term performance.

6. For the EN-1 mix with w/c of 0.60 , the reduction obtained in the ISAT results were increased with increasing EN-1 concentration, reduction percentages of $38 \%, 66 \%$ and $71 \%$ were obtained with EN-1 concentrations of 1:500, 1:300 and 1:100, respectively.

For the proposed mortar with EN-1 admixture and lime stone powder which was applied in the field, the following results were obtained:

1. A reduction in water loss from the canal is estimated since piezometers readings for the new lining with EN-1 are generally less than that of the ordinary lining indicating the effectiveness of EN-1 admixture in lining process as it minimizes the water head behind lining. This result is confirmed again since coefficient of permeability for core samples extracted from EN-1 lining is much less than that of ordinary lining by $61.50 \%$.

2. The permeability coefficient for laboratory samples of lining with EN-1 are less than ordinary lining by more than $81 \%$, that is more or less comparable with that of using lime stone powder in the mix which clarify the effectiveness of using both EN-1 admixture and the powder.

3. Compressive strength, after 28 days, for samples of lining containing EN-1 admixture, exceeded by $35 \%$ than the samples of traditional lining.

4. Long-term performance results for the applied mixes which was evaluated after one year in terms of both compressive and tensile strengths show that the compressive strength of the new proposed mix increases gradually with the time which ensures its efficiency, while its tensile strength decreases by about $50 \%$ which is maybe due to the absence of coarse aggregate.

5. Finally, the test results showed that using a chemical engineering admixture EN-1 especially for mortar is effective. However, it still needs further exponential studies and field applications.

Journal of Engineering Sciences, Assiut University, Faculty of Engineering, Vol. 41, No. 3, May, 2013,E-mail address: jes@aun.edu.eg 
M. I. Abu-Khashaba, Innovating impermeable concrete appropriate for canal lining using a specific mixing ratio and applying it to a pilot reach, pp. $900-918$

\section{Recommendations}

The results area satisfactory ample to assess the new proposed mix for lining from the permeability point of view. Nevertheless, further investigations are still required either in the laboratory or in the field. For example:

1. Different cement contents, sand/aggregate ratios, $w / c$ ratios and concentrations of EN-1 are required to be examined.

2. A complete chemical analysis for $E N-1$ is needed.

3. XRD analysis, scanning electron microscopic (SEM) are essential to have a complete picture about the impact of EN-1 on the concrete microstructure.

4. Evaluating the applicability of using discrete fibers beside EN-1 admixture with mortar and normal concrete mix as a case study in the nature is advisable.

\section{References}

[1] Kumar, B., and Deshpande, V., "Plane Bed Channel Resistance" International conference on Advances in Materials and Techniques for Infrastructure Development, NIT Calicut, India, 2011.

[2] Arshad, M., "Improving the Accuracy of Canal Seepage Detection through Geospatial Techniques", Ph.D. George Mason University, 2008.

[3] Amr A.M., "Effect of Non-Homogeneous Layers beneath a Floor of Hydraulic Structures on Seepage Characteristics", M.Sc. thesis, El-Minia Univ., 1997.

[4] Noury, M., Goharnejad, H., Noorzad, A., Shamsaie, A., and Goharnejad, A., "The Effect of Clay Blanket Thickness to Prevent Seepage in Dam Reservoir", Academic J. Inc., Research J. of Envir. Sciences, ISSN, pp. 1819-1829, 2010.

[5] Ahmed, A.R.M., "Investigation of Seepage Characteristics Under Hydraulic Structures Foundation (Supported by Sheet Pile) in Multi-Layers Soil", M.Sc., Faculty of Eng., Benha Univ., 2012.

[6] Jones J.A.A., "Soil Piping and Stream Channel Initiation", Water Resources Research 7 (3), pp. 602-610, 1976.

[7] Harr, M.E., "Groundwater and Seepage", Mcgraw-Hill, New York, 2008.

[8] Sommerfeldt, T.G., "Soil-Asphalt Mixture for Canal Seepage Control: Laboratory Study", Can. Agric. Eng. V.19 No. 2, pp. 111-115, 1977.

[9] Hoevenaars, J., Brouwer, C., and Hatcho, N., "Canals", Water Management Training Manual No 7", Int. Institute Forland Reclamation and Improvement \& FAO Land and Water Development Division, Provisional Edit., FAO, Rome, 1992.

[10]Burt C.M., Cardenas, M., and Grissa, M., "Canal Seepage Reduction by Soil Compaction", IA Technical Conference, Anaheim, CA, 2008.

[11] Prabhata, K., Swamee, Govinda C., Mishra, and Bhagu R., Chahar, "Comprehensive Design of Minimum Cost Irrigation Canal Sections", Journal of Irrigation and Drainage Engineering, pp. 322-327, 2000.

[12] Lauritzen, C.W., "Canal and Reservoir Linings", Soil and Water Conservation Research Branch, Agricultural Research Service, U.S., Dept. of Agriculture, pp. 58-65, 2004.

[13] Construction Research Institute, "Technical Report on the Evaluation of Lining using EN-1 Material for Branch (2) Right El-Nasr Canal", Egypt, 2003.

[14] The World-Wide Manufacturing Company, "Technical Reports on the Results of Using EN-1 Material for Improving Compaction in Some Applications Such as Base, Sub Base and Asphalt Layers", Egypt, 2002.

Journal of Engineering Sciences, Assiut University, Faculty of Engineering, Vol. 41, No. 3, May, 2013,E-mail address: jes@aun.edu.eg 
M. I. Abu-Khashaba, Innovating impermeable concrete appropriate for canal lining using a specific mixing ratio and applying it to a pilot reach, pp. $900-918$

ابتكار خرسانة غير منفذة مناسبة لأعمال تبطين الترع وتطبيقها فى الطبيعة على منطقة رائدة

الملخص

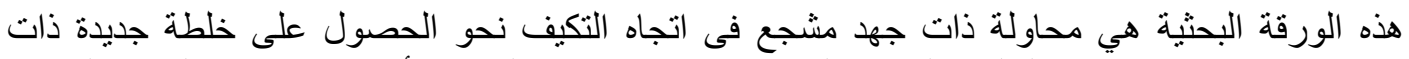

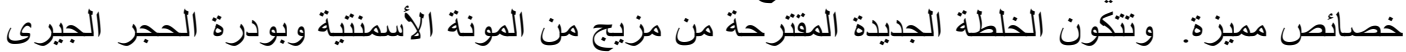

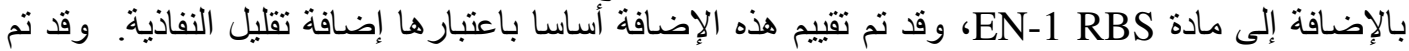

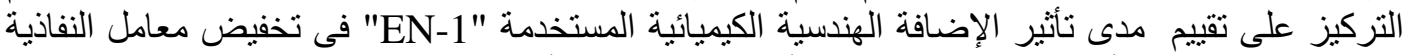

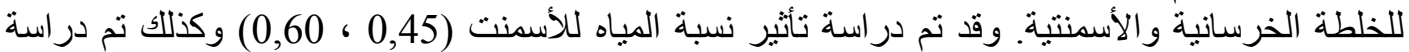

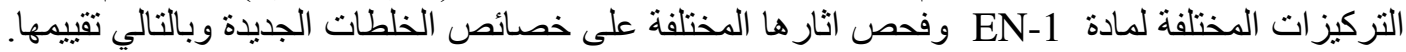

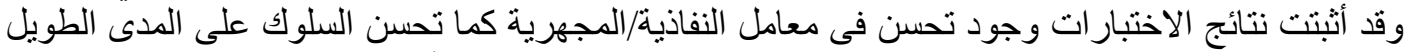

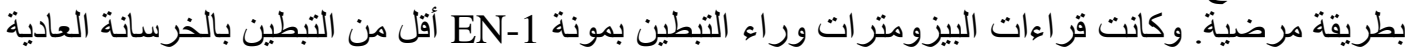

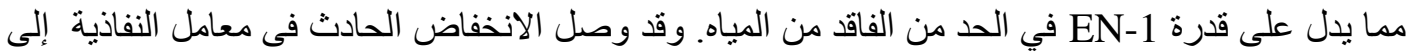

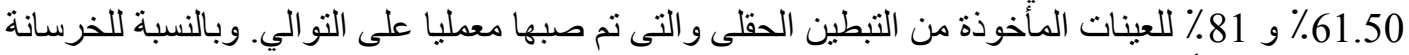

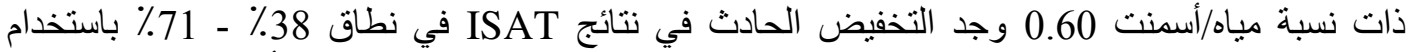

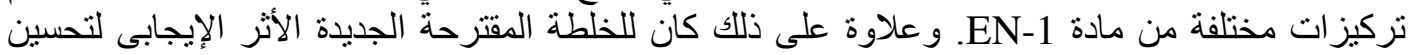

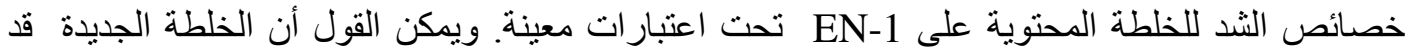
ساعدت على تخفيض معامل النفاذية على نحو مرض بالئ بالمقارنة مع الخلطات التقليدية وبالتالى يمكن القضاء التهاء

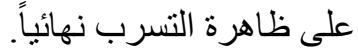

Journal of Engineering Sciences, Assiut University, Faculty of Engineering, Vol. 41, No. 3, May, 2013,E-mail address: jes@aun.edu.eg 